\title{
Social Exclusion and the Two-Tiered Healthcare System of Brazil ${ }^{1}$
}

\author{
Denisard Alves \\ University of São Paulo \\ Christopher Timmins \\ Yale University
}

\begin{abstract}
Resumo
No Brasil existe um sistema de saúde com dois acessos. Aqueles, com recursos, têm acesso ao sistema privado de saúde que fornece tratamento, com qualidade quando demandado, enquanto o restante da população tem que ser atendida pelo congestionado sistema de clínicas e hospitais públicos ou atendidos pelo sistema privado pago com recursos públicos. Dados de amostra de domicílios são utilizados para determinar quais grupos sócio-econômicos dependem do sistema público de saúde. As tendências demográficas atuais indicam que mais e mais pessoas vão utilizar o já congestionado sistema público de saúde nas próximas décadas. Um modelo estilizado de escolha é estimado e seus parâmetros são usados para se obter evidências, a partir de simulações, sobre as consequiências sobre o bem estar do aumento no congestionamento e sobre as políticas que poderiam reduzir seu impacto, como por exemplo subsídios no uso do sistema partícula de saúde.
\end{abstract}

\section{Palavras-chave}

sistema de saúde, exclusão social, máxima verossimilhança

\begin{abstract}
In Brazil, there exists a two-tiered system of healthcare access. Those with sufficient means have access to a private system of healthcare that provides quality treatment on demand, while the remainder of the country relies on an overburdened system of public clinics and hospitals. Household survey data are used to determine which socio-demographic groups rely most on this public healthcare system. Current demographic trends suggest that the public healthcare infrastructure will become more and more heavily used in the coming decades. A stylized model of healthcare choice is estimated, and its parameters are used to conduct counterfactual simulations of the welfare implications of this increased
\end{abstract}

${ }^{1}$ The authors are grateful to the Inter American Development Bank and to the Nemesis Project, a PRONEX program for financial support to this study. 
congestion, and of policies to offset it, like private healthcare subsidies.

\section{Keyword}

Maximum-likelihood, healthcare, social exclusion 


\section{Introduction}

In Brazil, there exists a two-tiered system of healthcare. Those with sufficient means, or whose employers provide health coverage, have access to a private system of healthcare that provides quality treatment on demand. The remainder of the country, conversely, relies on a system of public clinics and hospitals. As is the case with most public healthcare systems around the world, the Brazilian system is characterized by long waiting times, with the practical implication that those who are forced to rely on it spend more time being sick and, subsequently, have a diminished health stock.

This two-tiered system of healthcare is a particularly relevant concern in Brazil in light of recent changes in the country's socio-demographic structure. In 1990, only $6.7 \%$ of Brazil's population was over age 60 , but by 2010 this is expected to be $9.7 \%$ and by $2030,16.9 \%$ [World Bank (1994), (2000)]. During the last twenty years, family sizes amongst the poorer segments of Brazilian society (i.e., those who typically rely most on the public provision of healthcare), have been larger than in wealthier segments of society. This large population group has been aging, and is nearing a time when its healthcare needs will grow rapidly [Cutler and Meara (1998)]. Concerns have been raised that the Brazilian public health system will not be up to meeting this growing demand. In particular, already-long waiting times for treatment will continue to grow, with the practical implication that many of the poorest segments of society will receive no healthcare at all. This mechanism of social exclusion of the poor, elderly, and rural population will increase at the rate at which this segment of the Brazilian population is growing.

This mechanism may have long-run feedback effects as well. Growing demand due to the increasing size of the poor, elderly population, as well as the increasing cost of treatment for a limited supply of public health services, will mean that the poorest segments of Brazilian society will begin to lose access to healthcare. This will result in a declining health stock for the poor, reinforcing their socio-economic position. To the extent that the poor continue to have larger families (e.g., as a retirement-insurance mechanism or a source of labor for subsistence agriculture), this will lead to further strains on the public healthcare system in the future and, likely further failures.

This paper seeks to accomplish three tasks. First, we will use an outstanding set of Brazilian household survey data to characterize which social groups have access to private healthcare. In particular, we employ the 1998 PNAD, a broad household survey that includes detailed information on health, healthcare consumption, and, most importantly, the source from which one receives health services. We will argue that certain groups are systematically denied access to private healthcare in an indirect fashion. After identifying which groups are subject to this form of exclusion, the second part of our research will construct and empirically identify a stylized model of choice between alternative sources of healthcare provision, from which we will be able to derive a crude measure of the welfare consequences of the increased healthcare congestion costs that are likely to accompany the demographic transition we currently see in 
Brazil. With these welfare conclusions, in the final part of our research, we will be able to analyze the implications of policy alternatives such as private healthcare subsidies.

Section 2 of this paper describes describes the household survey data we will use for our analysis. Section 3 outlines our methodological approach for demonstrating that indirect exclusion exists and measuring its consequences, and reports how the implicit "price" of public healthcare varies across socio-demographic groups in Brazil. In Section 4, we carry out two counterfactual simulations. In the first, we examine the impacts of an increase in the implicit price of public healthcare, like that which would arise from the increased congestion that would accompany the predicted increases in healthcare demand in Brazil. In the second simulation, we consider the impact of a private healthcare subsidy being provided by the government, making that option more accessible to groups who had previously been able to afford only public healthcare. Given the propensity of individuals to switch their source of healthcare provision, we find that such a policy might only result in rent transfers to those segments of society that we would not consider to be "excluded". Section 5 concludes by suggesting limitations to, and possible extensions of, this research.

\section{Data}

The 1998 PNAD is an annual household survey on socio-economic conditions of the Brazilian population under the responsibility o9f the Instituto Brasileiro de Geografia e Estastistica (IBGE).The 1998 PNAD had a special supplement dealing with the health conditions of the Brazilian population. The supplement includestetailed information on health. The survey covers 344,975 individuals and 98,166 households $^{2}$. In the analysis, however, the number of observations will be smaller due Use of this survey data presents a number of advantages. First, it is one of the only surveys to collect data on health of the population in a consistent fashion. Second, data collection on health come with the full set of socio-economic variables on the individuals and on the household. Still, the collection of such data relies on the training of data enumerators to record health status. Thus, when looking at reported illnesses, the accuracy might not be as high as it would be if medical professionals were examining the individuals and reporting their illness.

The PNAD data set also presents some disadvantages -- it is restricted to the urban sector in the northern region of Brazil and is, therefore, not representative of the whole northen region

${ }^{2}$ In the analysis the number of household observations is smaller due to missing data in some variables. Used in the analysis. But even excluding missing data from the analysis due, for instance, to missing data for household income still permits the use of close to 90,000 observations on households. 
of Brazil. However, the data set covers pretty well the remaining regions of Brazil and the exclusion of the rural north does not harm the representability of the PNAD survey to the extent that the rural population in the north is very scarce. In our analysis we will use the household data set instead of the larger individual sample data. The reason is that decision on health is a major decision making process and is assumed to be a household decision. The analysis will take care of important characteristics of individuals within the household, as for instance, taking into account the proportion of children and the elderly people within the household because they are important aspects for the decision making process on health. Table 2 shows some major characteristics of the data set.

Variable With_HP is the proportion of the household heads who has a private health insurance paid by himself or by his employer. It amounts to $17 \%$ of the total household heads. The remaining households use the public health system. Variable PrivHP gives the household who pay their own health plan. Whopay shows the proportion of people having employer-provide private health insurance. The average household income is $\mathrm{R} \$ 962.50$ monthly. The average payment of health insurance for the $6.9 \%$ who pay their own medical insurance is $\mathrm{R} \$ 150.31$ and their average household income is $\mathrm{R} \$ 2137.50$ and $\mathrm{R} \$ 781.19$ of household per capita income. Income reported in Table 2 is the average household per capita income. Households who pays their own health plan have per capita income more than twice as much as the mean household per capita income estimated with the household sample data.

The Metro variable gives the proportion of the household heads living in Brazilian metropolitan areas. Urban gives the proportion of household heads living in urban areas. Age60 is variable that specifying the proportion of people in the household above 60 years of age. Variable f_kind2 gives the proportion of people bellow age 14 .

The proportion of the households that did not report any kind of illness is $49.1 \%$. Close to $51 \%$ reported some kind of illness and some of than reported as being stroke by two or more illness at the same time. The proportion of people looking for any kind of medical treatment in the last two weeks is $13.1 \%$. Table 1 was built using the evaluation of the quality of the health system using the perceived quality of attendment of those $13.1 \%$ of the households who looked for medical treatment in the last two weeks. The reported illness are self explanatory and they are the illness reported by the head of the household.

The set of race-differentiation variables are White, Mixed, Black and Yellow. Yellow are mainly the Asian descended household heads. The proportion of blacks is quite small, however, a large part of those people include in the mixed racial group are actually black people.

The characteristics of the private health plans acquired by 6,639 head of households are presented in the bottom part Table 2. These characteristics are used in the estimation of the shadow price for public health plans in a hedonic price regression with a Heckman correction and the results are presented in Table 5. All the attributes, are defined by a set of dummy variables permitting thus a complete description of the type of private health insurance available in Brazil today.

The variable plcons is one when the health plan covers doctors appointment and zero otherwise. 
The value of .9804 , presented in Table 2, means that almost all health insurance bought by head of households coves visits to doctors. Pllist is one when the health insurance policy present a list of authorized doctors, hospitals and laboratories that can be used by the policy holders and is zero otherwise. $92.47 \%$ of the private health insurance policies present a list of authorized doctors, hospitals and laboratories. The value for variable plreemb indicates that $30.99 \%$ of the health plans permit reimbursement of medical expenses when the individual is attended by doctors or health centers not affiliated to the health plan. Variable called plother indicates that $81.15 \%$ of the policy holders can be attended by doctors, hospitals and laboratories in cities others than the one they reside. pldent indicates that only $21.94 \%$ hold health insurance covering dental treatment. It is possible to observe that this attribute is not a widespread characteristic of the private health insurance. Plans having this attribute are more expensive than the ones that do not hate it. Paymore is a variable capturing the fact that some health insurance policies impose a limit in total medical expenses and anything above this limit would have to be paid by the policy holder $^{3}$. Variable plexam indicates that $95.60 \%$ of the private health plan allow policy holder to take complementary lab exams during treatment.92.83\% of the private policy holders are allowed to be covered for hospitalization. This facet of the private health plan is indicated by variable plinter. Variable platend indicates that $80.54 \%$ of policy holders are allowed to be attended by medical services under contract with the heath insurance company. Very few health plans cover the acquisition of medicines and drugs. Plmedic indicates that this attribute is very special and covers only $4.85 \%$ of the private health insurance holders. Among the health insurance holder, only $3.07 \%$ allow dental treatment. This aspect of the health insurance is represented by variable odonto in Table 2 .

\section{Research Methodology}

In order to characterize indirect exclusion from private healthcare in Brazil, we adopt a two-pronged methodological approach. First, we employ the detailed survey information in the 1998 PNAD data set, described in Section 2, to determine, generally, which groups in Brazilian society have access to private health insurance and which rely on public healthcare. Being relegated to public healthcare is not a direct form of exclusion, but rather one based on relative prices for private and public healthcare that may be different for individuals from different segments of society. Moreover, differences in employment patterns for individuals from different socio-economic groups will influence their access to employer-provided private health

\footnotetext{
${ }^{3}$ It is the only attribute among the 11 attributes where the dummy variable assumes the value of one when it indicates a detrimental characteristic
} of the health plan. 
insurance. $^{4}$

\subsection{Public v. Private Healthcare and Brazilian Socio-Demographic Groups}

$$
P\left(y_{i}=1\right)=\Phi\left(X_{i, j}^{\prime} \beta\right)
$$

We expect certain groups, based on race, education, and location in Brazil, to be systematically $\mathrm{m}$ ore relian $\mathrm{t}$ on the public healthcare system. First, we investigate which groups fall into this category with a simple Probit regression [Greene (2000)] of the following form: where

$y_{i}=$ form of healthcare coverage for individual $i(1=$ private, $0=$ public $)$

$X_{i}=$ socio-economic attributes of individual $i$; these include

- Race (Black, Asian, Mixed, White)

- Age

- Education is defined by years of schooling.

- Household Income

- Regional Indicators:

- Percentage of Persons in the Household with less than fourteen y ears of

age

- Percentage of People above 60 years of Age

- Household Income: the total sum of wage and other types of income of individuals living in the household.

\footnotetext{
${ }^{4}$ We avoid this difficult issue (i.e., health insurance as an attribute of a job for which an individual may or may not face a corresponding reduction in pay) by considering only those individuals who either buy private insurance directly (i.e., those who do not receive it through an employer) or use the SUS.
} 
- Migrator is one if the individual is outside the place where he or she was born and zero otherwise.

household.

- $\mathrm{f} \_$kind 2 is proportion of people bellow fourteen years of age living in the

- Age60 is the proportion of people the age of sixty years living in the household.

The results of this regression, which are found in Table 3, correspond to general perceptions about Brazilian healthcare. Those who tend to be more reliant on the public system are less educated, male, come from the Black and Mixed racial groups and from the Northern, Center western region of Brazil, have lower incomes, and are old people. The presence of people above sixty years of age is highly significant and the presence of people bellow fourteen years of age does not make a difference in terms of making the household going into the private health plan. Given the results described in Table 1 regarding differences in the quality of healthcare across providers, this alone could be considered evidence of exclusion of these groups.

Table 4 provides additional evidence along these lines. Specifically, it presents the results of a number of Probit regressions in which a dummy variable indicating that an individual has suffered from a particular disease (e.g., depression, arthritis, cancer, diabetes, respiratory ailment, hypertension, cardiac disease, tuberculosis, cirrhosis, tendinitis, and kidney disease) is regressed on a set of individual attributes, including the form of healthcare provision (i.e., SUS v. private) that the individual uses. The idea here is that an individual's health stock, which determines how likely he is to suffer from any of these ailments, is, in part, determined by the quality of the healthcare he receives. An individual who relies on the public system might, therefore, receive lower quality care, or less care in general (if waiting times for treatment are worse), leading to a lower health stock and a higher likelihood of disease. These results should be interpreted with extreme caution, however, as we would suspect the form of healthcare provision to be simultaneously determined with the individual's health stock; e.g., an individual who knows he is likely to develop cancer might purchase private health insurance in order to guarantee himself a higher quality of care. The presence of an endogenous variable in a Probit regression can potentially lead to inconsistent estimates of all the model's parameters.

The results, however, are very much consistent with a priori expectations about health and about the Brazilian health system Women, generally, are less likely to suffer from almost all diseases but Cirrhose. Women seems to be healthier than man. Higher income follows good health, meaning that poor people are more likely to suffer from some of the illness defined for the PNAD survey. One important point is that people with private health plan- either self paid or employer paid -are more likely to suffer from some of the illness, while healthier people are less likely to go to a private paid health plan The illness seems to strike more the Northeastern regions. People from the Southern and Southeastern regions are more 
likely to report cardiac, cancer, depression and respiratory diseases.

\subsection{A Model of Individual Healthcare Choice}

While describing which elements of Brazilian society are more likely to rely on publicly provided healthcare, the preceding analysis does not provide any way of measuring the welfare consequences of this indirect form of exclusion. In order to do so, we need to develop a more elaborate model that takes into account the fact that individuals optimally choose what form of health insurance to obtain in the face of market prices and a budget constraint. The second part of our empirical analysis develops such a model. The binding constraints on the scope of the conclusions that can be taken away from this model come from the lack of data describing individuals' full income endowments and actual expenditure patterns on health and non-health commodities over time. Instead, the model takes a stylized view, describing the individual's choice of health coverage as a choice between alternative types of insurance in a static context. To the extent that individuals change health insurance status during the course of their life, this may bias our answers.

In particular, we assume that individual $i$ chooses that form of healthcare provision in order to maximize a utility function of the form:

$$
U\left(C_{i}, H_{i}\right)=C_{i}^{\alpha_{i}} H_{i}^{l-\alpha_{i}}
$$

subject to a simple budget constraint:

$$
C_{i}+P_{i}^{H} H_{i}=I_{i}
$$

$C_{i}$ represents $i$ 's consumption of a composite numeraire commodity, $H_{i}$ represents the consumption of effective healthcare services (the price for these services, $P_{i}^{H}$ is allowed to differ by individual, and to reflect the quality of the nominal healthcare consumed), and $I_{i}$ represents the individual's income. $P_{i}^{H}$ will also differ according to the form of healthcare provision chosen; i.e., $P_{i}^{S}$ for SUS healthcare and $P_{i}^{P}$ for privately provided healthcare. The chief source of difficulty in this analysis is that $P_{i}^{S}$ is not observed (all SUS healthcare is nominally free), but is rather only a shadow price on SUS healthcare consumption.

Utility maximization subject to this budget constraint yields the following indirect utility function:

$$
V\left(P_{i}^{H}, I_{i}\right)=\left(\alpha_{i} I_{i}\right)^{\alpha_{i}}\left(\frac{\left(1-\alpha_{i}\right) I_{i}}{P_{i}^{H}}\right)^{l-\alpha_{i}}
$$

which differs by whether the individual chooses SUS healthcare $\left(V\left(P_{i}^{S}, I_{i}\right)\right)$ or private healthcare $\left(V\left(P_{i}^{P}, I_{i}\right)\right)$. Taking the optimal allocation of income between composite 
consumption and healthcare as given, individual $i$ 's choice between the two forms of healthcare provision can be modeled as a comparison of these two indirect utility functions. In particular, individual i will choose SUS healthcare as long as:

$$
V\left(P_{i}^{S}, I_{i}\right) \geq V\left(P_{i}^{P}, I_{i}\right)
$$

Because of the simple functional forms that we have employed, this boils down to $P_{i}^{S} \# P_{i}^{P}$. The price of an effective unit of public healthcare is not an observed magnitude; nominally, public healthcare is free to everyone in Brazil. It has a price, however, in the form of time in and disutility of crowded waiting rooms, etc... (see discussion in Section 2). We would expect this price to differ across individuals according to their opportunity cost of time, preferences for cleanliness, and disutility of congestion; i.e. differences for which we hope to be able to control with a set of observable individual attributes $\left(X_{i}\right)$.

The available data ollow us to recover each individual's shadow price for an effective unit of public healthcare by using inequality (4.2.4). Once we have done so, we will have all the tools necessary to consider the welfare impacts of an increase in the congestion costs associated with receiving health services from the SUS. In particular, assuming that the individual chooses the healthcare option that maximizes his indirect utility (with the individual's perception of the quality difference between public and private provision factored into that price), private healthcare will be chosen if $P_{i}^{P} \# P_{i}^{S} . P_{i}^{P}$ is observed in available data. ${ }^{5}$ We parameterize the natural logarithm of $P_{i}{ }^{S}$ as a linear function of individual attributes $\left(X_{i}\right)$ and an unobservable determinant $\left({ }_{i}\right)$, which is assumed to be identically and independently normally distributed with a unit variance and zero mean. The choice of private health coverage is then determined by the following condition being satisfied:

$$
\ln P_{i}^{p} \leq X_{i}^{p} \beta+\varepsilon_{i}
$$

\footnotetext{
${ }^{5}$ In particular, we observe in PNAD data the price of the private health insurance paid for everyone who opted for that form of coverage. We impute private health insurance premiums for the rest of the sample by (1) regressing the observed private premiums on individual attributes and attributes of the policy, (2) controlling for the selection into private healthcare provision with a Heckman-correction term- the results of the Heckman procedure is reported in Table 5- , and (3) fitting premiums for all individuals for a standardized policy. In particular, the standardization we adopt sets all of the attributes of the healthcare policy to their simplest values -- i.e., to give the price of a policy without any "bells or whistles". This creates a level playing ground for comparison of the individual's decision between public and private coverage.
} 
which will be the case if:

$$
\ln P_{i}^{p}-X_{i}^{p}-X_{i}^{\prime} \beta \leq \varepsilon_{i}
$$

which occurs with probability $1-M\left(\ln P_{i}^{P}-X_{i} ! \exists\right)$. Similarly, the probability that individual $i$ chooses public health coverage is given by $M\left(\ln P_{i}^{P}-X_{i} ! \exists\right)$. We can therefore write the likelihood of observing all of the health coverage choices of the individuals in the data set $\left(y_{i}\right)$, given their observable attributes $\left(X_{i}\right)$ and private healthcare price $\left(P_{i}{ }^{P}\right)$ as:

$$
L\left(\bar{y}, \bar{X}, \bar{P}^{p} ; \beta\right)=\prod_{y_{i}=0}\left[\Phi\left(\ln P_{i}^{p}-X^{\prime} \beta\right)\right] \prod_{y_{i}=1}\left[1-\Phi\left(\ln P_{i}^{p}-X_{i}^{\prime} \beta\right)\right]
$$

This likelihood function is maximized over the parameter vector, $\exists$, using data describing the decisions and attributes of a 10\% subsample of household heads in the PNAD. The use of only household heads eliminates the correlation in insurance type between members of a household that exists in the full data set. Eliminating data with missing observations for some variables, this yields a sample size of $\mathrm{N}=8267$. Coefficient estimates and standard errors are reported in Table 6.

Parameter estimates generally have the expected sign, and tend to be statistically significant. Those who we would expect to have greater disutility from congestion, etc... (i.e., from having a greater opportunity cost of time) face a higher imputed price for SUS healthcare. This is true of older and more educated individuals, although once individuals are over the age of 60 (i.e., when they begin to retire), their imputed SUS healthcare price falls. Individuals with higher incomes face a higher price, also because of a greater opportunity cost of time, and urban individuals face a greater cost than rural individuals, possibly because congestion problems are worse in the cities. Individuals in the South, Southeast, and Center-West regions of Brazil face higher prices than those in the North and Northeast, and Blacks and those in the Mixed racial category face lower prices than Whites, while Asians face higher prices.

As a measure of model fit, we can compare the predicted health coverage decisions of this model with the decisions observed in the data. The model does well, correctly predicting the choices of $87 \%$ of all individuals. When the model fails to predict correctly, it tends to be in the case of incorrectly forecasting the choices made by those individuals who opt for private health coverage; i.e., high-income, more educated, and older (younger than 60 years) individuals.

\section{Results and Policy Analysis}




\subsection{Analyzing Welfare Effects of a Change in the Price of Public Healthcare}

The initial goal of this research was to determine which groups in Brazilian society would suffer the most as a result of the increasing congestion of the public healthcare infrastructure that will likely accompany the socio-demographic trends we are currently observing. In order to measure the welfare cost of increased waiting time for public health provision, which might result from an increase in the number of elderly Brazilians relying on the SUS without a corresponding increase in supply, we need only consider the effect on different individuals in the sample if the price of public healthcare were to increase (e.g., by $50 \%$ ), taking into account the optimizing insurance decision each person makes to this price increase. Many individuals who had chosen public healthcare, for example, might stick with that choice and bear the brunt of the price increase, while others might find it optimal to pay more and switch to private healthcare. Those who had chosen private health coverage prior to the price increase would experience no change in price or disposable income. We simulate the decisions of each individual in the data set, backing-out the overall change in the price of receiving healthcare he or she faces after all is said and done. Finally, we consider the difference in the natural logarithms of the prices ultimately faced by each individual, before and after the price change. This measure provides us with a proportional measure of the compensating variation in income needed to maintain the same level of utility:

$$
\ln P_{i}^{H^{\prime}}-\ln P_{i}^{H}=\frac{1}{1-\alpha_{i}}\left(\ln I_{i}^{\prime}-\ln I_{i}\right)
$$

where $P_{i}^{H !}$ and $I_{i}{ }^{\prime}$ represent the price of healthcare provision and the accompanying required level of income needed to reach the original level of utility, after the increase in the price of SUS health coverage. Note that we cannot calculate the compensating variation in income directly, because we are unable to determine $\forall_{i}$ for each individual. This results from the fact that we do not observe an individual's full income endowment (i.e., an endowment including the value of available time, etc...) - rather, we only see the individual's monetary income, which is not expended at all if SUS healthcare is employed. This means that it is impossible to ultimately determine whether the difference in log prices is attributable to a compensating variation in income, or to heterogeneity in preferences. For the following discussion, we assume the former.

In order to quickly summarize the welfare implications of an increase in the price of SUS healthcare, like that which would accompany increasing congestion of that system, we regress this proportional measure on a vector of socio-demographic attributes, we are able to determine which groups in Brazilian society will suffer the most. The difference in 
magnitude of the effect across groups is something that we could not uncover from the simple Probit analysis described in Section 4.1, because that analysis did not describe how different types of individuals' behaviors would change in response to a price change. In all, the model predicts that $6.6 \%$ of all individuals consuming public healthcare prior to the price change would switch from public to private health coverage in response to this simulated price increase. Accounting for optimizing responses is therefore important.

The results of this regression appear in Table 7. Those in the South (i.e., the excluded region) fare worse than those in the rest of Brazil, especially the Center-West and Southeast. Blacks and those in the Mixed racial group fare worse than Whites, while Asians generally do better (owing to their greater predisposition to have been using private healthcare before the price increase). Older individuals do better (as they are also more likely to have been using private healthcare), until they reach the age of 60 , at which point they generally rely more on public healthcare and do much worse. Men generally fare worse than women, while those with more education and higher levels of income do better in the face of rising SUS prices, again reflecting predispositions towards using private health coverage.

Interpreting the results of this welfare analysis are complicated by the fact that we do not know whether the magnitudes we observe are differences in the level of income required to reach the original level of utility, or whether they simply reflect differences in individuals' preferences for healthcare consumption (i.e., $\forall_{i}$ ). Assuming that $I_{i}$ is the level of household income reported in the PNAD survey, however, we can calculate expenditure shares for health coverage based on the observed prices for private healthcare and the imputed prices for SUS healthcare. We do so for each individual in the $10 \%$ sample used above, and use them to calculate explicit measures of the compensating variation in income required to offset the increase in the price of SUS healthcare simulated above. Table 8 shows how these CV measures vary with observable socio-demographic attributes. The results differ in some ways from those in Table 6. In particular, increasingly educated individuals are worse-off, except for the highest education group. Blacks, Asians, and those in the Mixed racial group all fare better than Whites, and older individuals (both above and below the age of 60) fare worse. The most striking difference between these results and those presented in Table 6, which calls into question the validity of the assumption about income, is that wealthier individuals are made worse-off than poorer individuals by the increase in the SUS price - it is precisely these individuals that we would expect to be able to switch more easily to private health coverage, if they were not using it already, in response to an increase in the price of public coverage. To the extent that these individuals could not switch, however, we might expect that they would suffer most from increased congestion, given their higher opportunity cost of time.

\subsection{Analyzing the Welfare Effects of a Private Healthcare Subsidy}


The apparatus developed above also allows us to consider the implications of counterfactual policies designed to offset increasing congestion in the provision of public healthcare, where a simple reduced-form analysis, like that described at the start of Section 4.1, cannot. In particular, we can consider the implication for individuals' optimizing choices of a private healthcare subsidy, designed to expand the individual's budget constraint only if the income is used for the purchase of private healthcare. The welfare implications of such a policy could then (with better data describing the full income endowment) be compared to the implications of a simple income subsidy that could be used for any sort of consumption, indicating the value of a relatively paternalistic policy.

In the absence of such data, we consider the welfare consequences of a simple $50 \%$ price subsidization of private healthcare (i.e., the government pays 50 cents on every 1 real spent by the individual on private healthcare). In order to describe how the resulting welfare gains (again, a proportional measure of the compensating variation in income, assuming homogenous preferences, after the optimizing provider of healthcare is chosen ) фiffer across socio-demographic groups, we regress them on a vector of socio-demographic attributes. The results of this regression are described in Table 9. Negative numbers describe reductions in income that return individuals to their original levels of utility (i.e., indicating a benefit). Individuals in the Center-West and Southeast regions seem to benefit most from this price subsidy, while those in the North and Northeast benefit only marginally more than those in the South. Whites and Asians benefit more than Blacks and those in the Mixed racial group, and those with higher levels of education benefit more than those with less education. Similarly, richer individuals, women, and older individuals (under the age of 60) benefit more from the subsidy. Generally, these relative benefits reflect a greater predisposition towards (or propensity to switch to) private healthcare provision.

The natural question is how might such a private healthcare subsidization policy be targeted to benefit those individuals who would suffer most under an increase in the price of public care. To the extent that such subsidies, when applied broadly, seem to benefit highincome, high-education individuals, they simply represent a transfer of rents, since those individuals suffer less under the increasing price of public care than do the poor anyway. One possible option would be to implement the subsidy as part of an income tax collection regime, where participation criteria could be easily be established so as to allow the subsidy to be used only by low income residents. Problems of fraud in the reporting of private healthcare expenditures might make this approach difficult, however. Instead, we might

${ }^{6}$ The model predicts that approximately $13.3 \%$ of all individuals consuming public healthcare prior to the price subsidy would switch to private health coverage. With such a large increase in the demand for private healthcare, the government might want to undertake policies to facilitate entry by new private healthcare providers in addition to the subsidy, so as to avoid new congestion costs. 
focus on the results of the first counterfactual simulation, and target subsidy funds geographically so as to reach those individuals who both lose most under the simulated increases in public prices. Such is true, for example, of Black and Mixed race residents of the South, Southeast, and Center-West, particularly those with low levels of education. Generally, these regions are viewed as being the developed regions of Brazil, and conventional wisdom might suggest that more would be gained by targeting resources to the less developed North and Northeast. The results of this analysis, however, suggest that it is these excluded groups living in the developed parts of Brazil that would benefit the most from intervention to make private healthcare more affordable.

Finally, dealing with the impacts of rising public healthcare costs on the elderly (a major concern given current socio-demographic trends) by subsidizing the consumption of private healthcare seems more problematic, since those over the age of 60 are predicted to benefit less than most other groups from this policy. This arises from the model's prediction that members of this group are not as likely to switch to private health coverage even with the change in relative prices. Indeed, in order to limit the adverse effects on this group of rising congestion in public healthcare consumption without affecting huge rent transfers to those who are less adversely impacted, the government will likely have to take steps to directly increase the supply of public healthcare provision.

\section{Conclusions and Extensions}

The goal of this analysis was to determine which groups in Brazilian society were most "excluded" from private healthcare. Private healthcare is generally considered to be of a higher quality level; this perception is generally supported by the PNAD survey data. Such exclusion is not of a direct form as would be racial exclusion from a club, but is rather based on individuals facing different relative prices for public and private healthcare owing to differences in their observable attributes and preferences for healthcare consumption. Our initial analysis of PNAD survey data documents what is generally perceived to be the case -that poor, rural, Black and Mixed-race Brazilians tend to rely more on public healthcare. This alone would not necessarily represent a source of social inequity, except that we expect the price of this form of healthcare to increase in the coming decades owing to the increasing congestion of an already-overburdened system, and we expect these groups to suffer most. In order to determine how these price increases would be distributed over different socio-economic groups, we need a more elaborate model of optimal individual decision-making; i.e., a model that allows us to determine how individuals would behave

${ }^{7}$ Reaching these particular racial groups might be difficult, unless the subsidies took the form of monies to establish new private healthcare facilities in racially segregated neighborhoods. 
under current and counterfactual relative-price scenarios. Operating under constraints of data availability, we assumed that each individual was required to consume a single unit of some form of healthcare coverage (i.e., public or private), and that differences in the quality of care across forms would be internalized in the price confronting the individual. Differences in price might also arise from observable individual attributes (i.e., a direct form of discrimination), or from an individual's preferences for healthcare consumption (e.g., individuals with strong preferences for healthcare consumption might face an even higher price for an effective unit of public care than a similar individual who had weak preferences for healthcare consumption), but available data do not allow us to identify these effects. From a simple and stylized model of utility maximization, we were able to recover estimates of the price of public health coverage, and used those estimates to infer which sociodemographic groups would suffer most from an increase in the congestion of the public healthcare system. While the conclusions of this analysis conform to the general perceptions regarding race, education, and income groups, they suggest that the groups most at risk from an increase in the price of SUS healthcare would be the excluded racial and education groups in the southern half of the country, which, while developed, exhibits a great deal of social and income inequality.

With even more detailed data on the attributes of the alternative forms of healthcare provision, we might also be able to build a more realistic hedonic model in which individuals with weak preferences for healthcare would choose to consume the type that exhibits low-levels of amenities and a low price, while those who derive a great deal of utility from the consumption of healthcare might choose a "deluxe" form of healthcare provision. This could be important in predicting how different individuals would respond to an increase in the congestion of the public system, which would increase waiting times for treatment (i.e., a specific trait of the healthcare commodity). We might find, for example, that certain socio-demographic groups exhibit a strong distaste for waiting time, and they would thus tend to bear more of the burden of increasing congestion of the SUS. Other survey data (e.g., the 1997 PPV) provide some indication of waiting time incurred in the receipt of healthcare services, but these data exhibit many missing observations, and it is unclear whether they will be appropriate for such an analysis.

Even with the limitations and simplifications described above, the current model is suggestive of which groups are most likely to suffer from the increasing congestion of the public healthcare infrastructure that is likely to accompany current demographic trends in Brazil. From an equity perspective, these groups are generally those about whom we are most worried, suggesting that some policy (i.e., subsidization of private healthcare or the expansion of the public infrastructure) must be undertaken. Which specific policy response to use depends upon which particular group we are most trying to help. 
Table 1

Perceptions of Healthcare Quality by Type

\begin{tabular}{|c|c|c|c|c|c|c|c|c|}
\hline \multirow[t]{2}{*}{ Region } & \multirow{2}{*}{$\begin{array}{c}\text { Health } \\
\text { Care } \\
\text { Type } \\
0=\text { SUS } \\
\text { 1=Private }\end{array}$} & \multirow{2}{*}{$\begin{array}{c}\% \text { Who } \\
\text { Received } \\
\text { Health } \\
\text { Care } \\
\text { Sought }\end{array}$} & \multicolumn{6}{|c|}{$\begin{array}{l}\text { Reason for failing to receive healthcare (for those seeking } \\
\text { healthcare during previous two weeks) }\end{array}$} \\
\hline & & & No Vacancy & $\begin{array}{l}\text { No Attending } \\
\text { Doctor }\end{array}$ & $\begin{array}{l}\text { No Attending } \\
\text { Expert }\end{array}$ & $\begin{array}{c}\text { Malfunc- } \\
\text { tioning } \\
\text { Equipment }\end{array}$ & $\begin{array}{c}\text { Had To Wait } \\
\text { Too Long }\end{array}$ & Other \\
\hline \multirow{2}{*}{ North } & 0 & 93.6 & 31.1 & 53.3 & 4.4 & 4.4 & 4.4 & 4.4 \\
\hline & 1 & 97.7 & 0 & 50 & 0 & 0 & 25 & 25 \\
\hline \multirow{2}{*}{$\mathrm{NE}$} & 0 & 93.8 & 39.5 & 29.7 & 10.3 & 4.9 & 5.4 & 10.3 \\
\hline & 1 & 98.2 & 15.4 & 7.7 & 15.4 & 0 & 7.7 & 53.9 \\
\hline \multirow{2}{*}{$\mathrm{CW}$} & 0 & 94.1 & 50 & 22.1 & 8.8 & 1.5 & 7.4 & 10.3 \\
\hline & 1 & 96.8 & 50 & 40 & 10 & 0 & 0 & 0 \\
\hline \multirow{2}{*}{ SE } & 0 & 95.4 & 43.1 & 28.8 & 13.1 & 5 & 3.8 & 6.3 \\
\hline & 1 & 98.8 & 52.9 & 23.5 & 0 & 0 & 0 & 23.5 \\
\hline \multirow{2}{*}{ South } & 0 & 94.7 & 61.6 & 17.2 & 3 & 0 & 4 & 7.1 \\
\hline & 1 & 99.1 & 33.3 & 16.7 & 16.7 & 0 & 0 & 33.3 \\
\hline \multirow{2}{*}{ All } & 0 & 94.6 & 45.6 & 28.5 & 9.3 & 3.6 & 4.9 & 8 \\
\hline & 1 & 98.5 & 36 & 24 & 8 & 0 & 4 & 28 \\
\hline
\end{tabular}


Table 2

Data Summary - Household Heads

$\mathrm{N}=98166$

\begin{tabular}{|c|c|c|c|}
\hline Variable & Mean & Variable & Mean \\
\hline Sex & 0.727 & Age & 44.524 \\
\hline Educ & 6.612 & Age60 & 0.176 \\
\hline Income & 338.591 & f_kind2 & 0.284 \\
\hline Black & 0.068 & PrivHP & 0.069 \\
\hline White & 0.526 & whopay & 0.101 \\
\hline Mixed & 0.400 & Arthrit & 0.148 \\
\hline Yellow & 0.004 & Cancer & 0.004 \\
\hline Urban & 0.831 & Cardiac & 0.074 \\
\hline Metro & 0.413 & Cirrhose & 0.003 \\
\hline dcwest & 0.109 & Backache & 0.312 \\
\hline dseast & 0.342 & Depress & 0.078 \\
\hline dsouth & 0.178 & Diabets & 0.037 \\
\hline dnorth & 0.068 & Hipert & 0.197 \\
\hline dneast & 0.302 & Kidney & 0.047 \\
\hline With_HP & 0.170 & Respir & 0.042 \\
\hline Migrator & 0.009 & Tendon & 0.032 \\
\hline Value & 79.474 & Tuberc & 0.002 \\
\hline Attend & 0.131 & Healthy & 0.491 \\
\hline
\end{tabular}




\begin{tabular}{|l|l|l|c|}
\hline \multicolumn{2}{|l|}{ Characteristics of Private Healthy Plan } \\
N=6639 & plexam & 0.956 \\
\hline \hline plcons & 0.980 & plinter & 0.929 \\
\hline pllist & 0.925 & platend & 0.805 \\
\hline plreemb & 0.310 & plmedic & 0.045 \\
\hline plother & 0.811 & odonto & 0.031 \\
\hline pldent & 0.219 & & \\
\hline paymore & 0.178 & & \\
\hline
\end{tabular}

Table 3

Probit Regression

$\mathrm{N}=82900, \log$ Likelihood $=-16753.661$

\begin{tabular}{|c|c|c|c|c|c|}
\hline Variable & Estimate & Standard Error & Variable & Estimate & Standard Error \\
\hline Sex & 0.0051 & 0.0173 & Dseast & 0.3056 & 0.0345 \\
\hline Educ & 0.1173 & 0.0020 & Dneast & 0.0823 & 0.0356 \\
\hline Income & 0.0003 & 0.00001 & Dsouth & 0.0411 & 0.0374 \\
\hline Black & -0.4785 & 0.0855 & Age & 0.0233 & 0.0008 \\
\hline White & -0.1862 & 0.0785 & Age60 & -0.2696 & 0.0290 \\
\hline Mixed & -0.4284 & 0.0799 & f_kind2 & -0.0195 & 0.0206 \\
\hline Dcwest & -0.0668 & 0.0409 & Constant & -3.3594 & 0.0964 \\
\hline
\end{tabular}

Table 4

Probit Regression

Determinants of Diseases 


\begin{tabular}{|c|c|c|c|c|c|c|}
\hline $\begin{array}{l}\text { Diseases } \\
\text { Variable }\end{array}$ & Arthrit & Cancer & Cardiac & Cirrhose & Backache & Depres \\
\hline Sex & $\begin{array}{l}-0.3636 \\
(29.867)^{*}\end{array}$ & $\begin{array}{l}-0.0801 \\
(-2.074)^{* *}\end{array}$ & $\begin{array}{l}-0.2590 \\
(-18.250)^{*}\end{array}$ & $\begin{array}{l}0.3099 \\
(5.621)^{*}\end{array}$ & $\begin{array}{l}-0.1864 \\
(-18.116)^{*}\end{array}$ & $\begin{array}{l}-0.5768 \\
(-42.920)^{*}\end{array}$ \\
\hline Age & $\begin{array}{l}0.0323 \\
(52.069)^{*}\end{array}$ & $\begin{array}{l}0.0168 \\
(7.935)^{*}\end{array}$ & $\begin{array}{l}0.0270 \\
(36.155)^{*}\end{array}$ & $\begin{array}{l}0.0096 \\
(4.333)^{*}\end{array}$ & $\begin{array}{l}0.0215 \\
(45.530)^{*}\end{array}$ & $\begin{array}{l}0.0129 \\
(19.772)^{*}\end{array}$ \\
\hline Educ & $\begin{array}{l}-0.0461 \\
(-27.706)^{*}\end{array}$ & $\begin{array}{r}0.0051 \\
(0.978)\end{array}$ & $\begin{array}{l}-0.0124 \\
(-6.447)^{*}\end{array}$ & $\begin{array}{l}-0.0275 \\
(-4.357)^{*}\end{array}$ & $\begin{array}{l}-0.0368 \\
(-29.233)^{*}\end{array}$ & $\begin{array}{l}-0.0050 \\
(-2.807)^{*}\end{array}$ \\
\hline Income & $\begin{array}{l}-0.00005 \\
(-4.307)^{*}\end{array}$ & $\begin{array}{l}-7.73 e-06 \\
(-0.263)\end{array}$ & $\begin{array}{l}-0.00002 \\
(-1.998)^{* *}\end{array}$ & $\begin{array}{l}-0.00003 \\
(-0.591)\end{array}$ & $\begin{array}{l}-0.00006 \\
(-7.246)^{*}\end{array}$ & $\begin{array}{l}-0.00006 \\
(-5.194)^{*}\end{array}$ \\
\hline Black & $\begin{array}{l}0.2166 \\
(2.308)^{* *}\end{array}$ & $\begin{array}{l}3.714 \\
(22.035)^{*}\end{array}$ & $\begin{array}{l}0.3320 \\
(3.214)^{*}\end{array}$ & $\begin{array}{l}0.0048 \\
(-0.014)\end{array}$ & $\begin{array}{l}0.1259 \\
(1.796)\end{array}$ & $\begin{array}{l}-0.1970 \\
(1.789)\end{array}$ \\
\hline White & $\begin{array}{l}0.2207 \\
(2.406)^{* *}\end{array}$ & $\begin{array}{c}3.1977 \\
(25.526)^{*}\end{array}$ & $\begin{array}{l}0.1884 \\
(1.866)\end{array}$ & $\begin{array}{l}0.0223 \\
(-0.069)\end{array}$ & $\begin{array}{l}0.1608 \\
(2.357)^{* *}\end{array}$ & $\begin{array}{l}0.2730 \\
(2.536)^{* *}\end{array}$ \\
\hline Mixed & $\begin{array}{l}0.2545 \\
(2.764)^{*}\end{array}$ & $\begin{array}{c}3.8188 \\
(25.907)^{*}\end{array}$ & $\begin{array}{l}0.1967 \\
(1.938)^{* *}\end{array}$ & $\begin{array}{l}0.1196 \\
(0.367)\end{array}$ & $\begin{array}{l}0.1610 \\
(2.349)^{* *}\end{array}$ & $\begin{array}{l}0.2719 \\
(2.515)^{* *}\end{array}$ \\
\hline Age60 & $\begin{array}{l}-0.1085 \\
(-5.474)^{*}\end{array}$ & $\begin{array}{l}0.0302 \\
(0.466)\end{array}$ & $\begin{array}{l}-0.0364 \\
(-1.560)\end{array}$ & $\begin{array}{l}-0.2681 \\
(-3.568)^{*}\end{array}$ & $\begin{array}{l}-0.2775 \\
(-16.240)^{*}\end{array}$ & $\begin{array}{l}-0.1887 \\
(-8.087)^{*}\end{array}$ \\
\hline f_kind2 & $\begin{array}{l}-0.0760^{*} \\
(-4.529)\end{array}$ & $\begin{array}{l}-0.1978 \\
(-2.934)^{*}\end{array}$ & $\begin{array}{l}-0.1109 \\
(-5.304)^{*}\end{array}$ & $\begin{array}{l}-0.1288 \\
(-2.320)^{* *}\end{array}$ & $\begin{array}{l}-0.0064 \\
(-0.545)\end{array}$ & $\begin{array}{l}-0.1018 \\
(-5.565)^{*}\end{array}$ \\
\hline dcwest & $\begin{array}{l}-0.3241 \\
(-12.958)^{*}\end{array}$ & $\begin{array}{l}0.2203 \\
(1.935)^{* *}\end{array}$ & $\begin{array}{l}0.0331 \\
(1.035)\end{array}$ & $\begin{array}{l}-0.0873 \\
(-1.053)\end{array}$ & $\begin{array}{l}-0.1318 \\
(-6.310)^{*}\end{array}$ & $\begin{array}{l}-0.0085 \\
(-0.284)\end{array}$ \\
\hline dseast & $\begin{array}{l}-0.5745 \\
(-26.363)^{*}\end{array}$ & $\begin{array}{l}0.2412 \\
(2.337)^{* *}\end{array}$ & $\begin{array}{l}-0.0355 \\
(-1.268)\end{array}$ & $\begin{array}{l}-0.01793 \\
(-2.450)^{* *}\end{array}$ & $\begin{array}{l}-0.2450 \\
(-13.413)^{*}\end{array}$ & $\begin{array}{l}-0.0581 \\
(-2.230)^{* *}\end{array}$ \\
\hline dneast & $\begin{array}{l}-0.3596 \\
(-17.034)^{*}\end{array}$ & $\begin{array}{l}0.0751 \\
(0.714)\end{array}$ & $\begin{array}{l}-0.1752 \\
(-6.222)^{*}\end{array}$ & $\begin{array}{l}-0.2243 \\
(-3.123)^{*}\end{array}$ & $\begin{array}{l}-0.0930 \\
(-5.168)^{*}\end{array}$ & $\begin{array}{l}-0.0772 \\
(-2.988)^{*}\end{array}$ \\
\hline dsouth & $\begin{array}{l}-0.3832 \\
(-16.065)^{*}\end{array}$ & $\begin{array}{l}0.3750 \\
(3.530)^{*}\end{array}$ & $\begin{array}{l}0.0631 \\
(2.087)^{* *}\end{array}$ & $\begin{array}{l}-0.1592 \\
(-1.911)^{* *}\end{array}$ & $\begin{array}{l}-0.1983 \\
(-9.918)^{*}\end{array}$ & $\begin{array}{l}0.0590 \\
(2.094)^{* *}\end{array}$ \\
\hline With_HP & $\begin{array}{l}-0.0434 \\
(-2.428)^{* *}\end{array}$ & $\begin{array}{l}-0.0383 \\
(-0.708)\end{array}$ & $\begin{array}{l}0.0430 \\
(2.177)^{* *}\end{array}$ & $\begin{array}{l}0.0266 \\
(0.409)\end{array}$ & $\begin{array}{l}0.0135 \\
(1.011)\end{array}$ & $\begin{array}{l}0.0002 \\
(0.008)\end{array}$ \\
\hline $\mathrm{N}$ & 95565 & 95565 & 95565 & 95565 & 95565 & 95565 \\
\hline $\begin{array}{l}\text { Log } \\
\text { Likelihood }\end{array}$ & -32729.57 & -2274.64 & -21995.40 & -1875.49 & -55542.89 & -24502.90 \\
\hline
\end{tabular}

\begin{tabular}{|l|l|l|l|l|l|l|l|}
\hline Diseases & Diabets & Hipert & Kidney & Respir & Tendon & Tuberc \\
Variable & & & & & & \\
\hline Sex & $\begin{array}{l}-0.1779 \\
(-10.124)^{*}\end{array}$ & $\begin{array}{l}-0.2975 \\
(-26.486) *\end{array}$ & $\begin{array}{l}-0.0095 \\
(-0.563)\end{array}$ & $\begin{array}{l}-0.1998 \\
(-12.069)^{*}\end{array}$ & $\begin{array}{l}-0.3358 \\
(-18.811)^{*}\end{array}$ & $\begin{array}{l}0.0935 \\
(1.484)\end{array}$ & $\begin{array}{l}0.3300 \\
(31.543)^{*}\end{array}$ \\
\hline Age & $\begin{array}{l}0.0290 \\
(30.030)^{*}\end{array}$ & $\begin{array}{l}0.0337 \\
(60.244)^{*}\end{array}$ & $\begin{array}{l}0.0130 \\
(16.570)^{*}\end{array}$ & $\begin{array}{l}0.0038 \\
(4.890)^{*}\end{array}$ & $\begin{array}{l}0.01105 \\
(12.620)^{*}\end{array}$ & $\begin{array}{l}0.0079 \\
(2.847)^{*}\end{array}$ & $\begin{array}{l}-0.0325 \\
(-70.269)^{*}\end{array}$ \\
\hline
\end{tabular}




\begin{tabular}{|c|c|c|c|c|c|c|c|}
\hline Educ & $\begin{array}{l}-0.0023 \\
(-0.973)\end{array}$ & $\begin{array}{l}0.0150 \\
(-10.564)^{*}\end{array}$ & $\begin{array}{l}-0.0333 \\
(-15.026)^{*}\end{array}$ & $\begin{array}{l}-0.0121 \\
(-5.638)^{*}\end{array}$ & $\begin{array}{l}0.0060 \\
(2.678)^{*}\end{array}$ & $\begin{array}{l}-0.0248 \\
(-2.877)^{*}\end{array}$ & $\begin{array}{l}0.0296 \\
(24.692)^{*}\end{array}$ \\
\hline Income & $\begin{array}{l}0.00003 \\
(2.289)^{* *}\end{array}$ & $\begin{array}{l}-0.00002 \\
(-1.885)\end{array}$ & $\begin{array}{l}-0.00009 \\
(-4.560)^{*}\end{array}$ & $\begin{array}{l}-0.000005 \\
(-0.360)\end{array}$ & $\begin{array}{l}0.00004 \\
(3.738)^{*}\end{array}$ & $\begin{array}{l}-0.0002 \\
(-1.589)\end{array}$ & $\begin{array}{l}0.00004 \\
(4.684)^{*}\end{array}$ \\
\hline Black & $\begin{array}{l}0.1286 \\
(1.150)\end{array}$ & $\begin{array}{l}0.3107 \\
(4.204)^{*}\end{array}$ & $\begin{array}{l}-0.0305 \\
(-0.266)\end{array}$ & $\begin{array}{l}0.2334 \\
(1.833)\end{array}$ & $\begin{array}{l}0.1738 \\
(1.264)\end{array}$ & $\begin{array}{l}-0.1437 \\
(-0.423)\end{array}$ & $\begin{array}{l}-0.2140 \\
(-3.266)^{*}\end{array}$ \\
\hline White & $\begin{array}{l}0.0138 \\
(0.127)\end{array}$ & $\begin{array}{l}0.0863 \\
(1.181)\end{array}$ & $\begin{array}{l}0.0148 \\
(0.132)\end{array}$ & $\begin{array}{l}0.2103 \\
(1.689)\end{array}$ & $\begin{array}{l}0.1964 \\
(1.468)\end{array}$ & $\begin{array}{l}-0.3173 \\
(-0.957)\end{array}$ & $\begin{array}{l}-0.1921 \\
(-3.024)^{*}\end{array}$ \\
\hline Mixed & $\begin{array}{l}0.0162 \\
(-0.148)\end{array}$ & $\begin{array}{l}0.1273 \\
(1.732)\end{array}$ & $\begin{array}{l}0.0134 \\
(0.120)\end{array}$ & $\begin{array}{l}0.2115 \\
(1.691)\end{array}$ & $\begin{array}{l}0.2212 \\
(1.645)\end{array}$ & $\begin{array}{l}-0.2295 \\
(-0.689)\end{array}$ & $\begin{array}{l}-0.1989 \\
(-3.112)^{*}\end{array}$ \\
\hline Age60 & $\begin{array}{l}-0.1718 \\
(-5.952)^{*}\end{array}$ & $\begin{array}{l}-0.1925 \\
(-10.469)^{*}\end{array}$ & $\begin{array}{l}-0.1600 \\
(-5.194)^{*}\end{array}$ & $\begin{array}{l}0.0279 \\
(9.076)^{*}\end{array}$ & $\begin{array}{l}-0.1186 \\
(-3.850)^{*}\end{array}$ & $\begin{array}{l}-0.2536 \\
(-2.585)^{*}\end{array}$ & $\begin{array}{l}0.1571 \\
(8.896)^{*}\end{array}$ \\
\hline f_kind2 & $\begin{array}{l}-0.1546 \\
(-5.498)^{*}\end{array}$ & $\begin{array}{l}-0.1099 \\
(-7.545)^{*}\end{array}$ & $\begin{array}{l}0.01118 \\
(0.594)\end{array}$ & $\begin{array}{l}-0.0241 \\
(-1.157)\end{array}$ & $\begin{array}{l}-0.0773 \\
(-3.214)^{*}\end{array}$ & $\begin{array}{l}-0.0220 \\
(-0.316)\end{array}$ & $\begin{array}{l}0.0382 \\
(3.452)^{*}\end{array}$ \\
\hline dcwest & $\begin{array}{l}-0.0700 \\
(-1.637)\end{array}$ & $\begin{array}{l}0.0909 \\
(3.653)^{*}\end{array}$ & $\begin{array}{l}0.0314 \\
(1.057)\end{array}$ & $\begin{array}{l}0.0566 \\
(1.600)\end{array}$ & $\begin{array}{l}-0.1783 \\
(-4.644)^{*}\end{array}$ & $\begin{array}{l}-0.1003 \\
(-0.727)\end{array}$ & $\begin{array}{l}0.1243 \\
(6.007)^{*}\end{array}$ \\
\hline dseast & $\begin{array}{l}0.0481 \\
(1.334)\end{array}$ & $\begin{array}{l}0.0794 \\
(3.646)^{*}\end{array}$ & $\begin{array}{l}-0.3460 \\
(-12.628)^{*}\end{array}$ & $\begin{array}{l}-0.0146 \\
(-0.466)\end{array}$ & $\begin{array}{l}-0.2185 \\
(-6.657)^{*}\end{array}$ & $\begin{array}{l}0.0542 \\
(0.486)\end{array}$ & $\begin{array}{l}0.2505 \\
(13.775)^{*}\end{array}$ \\
\hline dneast & $\begin{array}{l}-0.0585 \\
(-1.607)\end{array}$ & $\begin{array}{l}-0.0076 \\
(-0.348)\end{array}$ & $\begin{array}{l}-0.4078 \\
(-14.966)^{*}\end{array}$ & $\begin{array}{l}-0.1817 \\
(-5.711)^{*}\end{array}$ & $\begin{array}{l}-0.2026 \\
(-6.229)^{*}\end{array}$ & $\begin{array}{l}0.0503 \\
(0.461)\end{array}$ & $\begin{array}{l}0.1925 \\
(10.669)^{*}\end{array}$ \\
\hline dsouth & $\begin{array}{l}-0.0091 \\
(-0.231)\end{array}$ & $\begin{array}{l}0.0557 \\
(2.347)^{* * *}\end{array}$ & $\begin{array}{l}-0.2549 \\
(-8.443)^{*}\end{array}$ & $\begin{array}{l}0.1740 \\
(5.222)^{*}\end{array}$ & $\begin{array}{l}0.0488 \\
(1.409)\end{array}$ & $\begin{array}{l}0.0834 \\
(0.683)\end{array}$ & $\begin{array}{l}0.1482 \\
(7.479)^{*}\end{array}$ \\
\hline With_HP & $\begin{array}{l}0.1178 \\
(5.065)^{*}\end{array}$ & $\begin{array}{l}0.0961 \\
(6.489)^{*}\end{array}$ & $\begin{array}{l}-0.0512 \\
(-2.153)^{* *}\end{array}$ & $\begin{array}{l}-0.0048 \\
(-0.214)\end{array}$ & $\begin{array}{l}0.1397 \\
(6.128)^{*}\end{array}$ & $\begin{array}{l}-0.2064 \\
(-1.869)\end{array}$ & $\begin{array}{l}-0.0677 \\
(-5.327)^{*}\end{array}$ \\
\hline $\mathrm{N}$ & 95565 & 95565 & 95565 & 95565 & 95565 & 95565 & 95565 \\
\hline $\begin{array}{l}\text { Log } \\
\text { Likelihoo }\end{array}$ & -13340.13 & -40920.07 & -17382.01 & -16213.18 & -12853.73 & -1107.16 & -58161.94 \\
\hline
\end{tabular}

1-Z- statistics are in parentheses

* significance level for $1 \%$

** significance level for $5 \%$

Table 5

Heckman Procedure to Estimate the Price of the Public Health Services

$\mathrm{N}=82800, \quad$ Log Likelihood $=-27520.82$

\begin{tabular}{|l|l|l||l|c|c|}
\hline \multicolumn{1}{|c|}{ Variable } & Estimate & Standard Error & Variable & Estimate & Standard Error \\
\hline \hline Sex & 0.1914 & 0.0244 & pllist & 0.0280 & 0.0386 \\
\hline Educ & -0.0382 & 0.0492 & plreemb & 0.1252 & 0.0216 \\
\hline Income & 0.00001 & 0.00001 & plother & 0.2927 & 0.0268 \\
\hline Black & -0.0087 & 0.0557 & plcons & -0.7845 & 0.0625 \\
\hline White & -0.1418 & 0.0276 & plexam & 0.1088 & 0.0559 \\
\hline Yellow & 0.1438 & 0.9555 & plinter & 0.5942 & 0.0413 \\
\hline dcwest & -0.1110 & 0.0564 & pldent & -0.3128 & 0.0235 \\
\hline dseast & -0.2026 & 0.0484 & plmedic & 0.0395 & 0.0440 \\
\hline dneast & -0.0128 & 0.0492 & odonto & -0.0045 & 0.0564 \\
\hline
\end{tabular}




\begin{tabular}{|c|c|c|c|c|c|}
\hline dsouth & -0.1704 & 0.0514 & paymore & -0.3670 & 0.0257 \\
\hline age & -0.0001 & 0.0013 & depen & 0.1983 & 0.0627 \\
\hline Age60 & 0.1520 & 0.0391 & fam_dep & 0.1447 & 0.0620 \\
\hline f_kind2 & 0.0492 & 0.0278 & Constant & 6.6104 & 0.1695 \\
\hline platend & -0.0104 & 0.0243 & & & \\
\hline \multicolumn{6}{|l|}{ Select } \\
\hline Sex & -0.0098 & 0.0163 & dseast & 0.2822 & 0.0319 \\
\hline Educ & 0.1161 & 0.0018 & dneast & 0.0626 & 0.0328 \\
\hline Income & 0.0003 & 0.00001 & dsouth & 0.0653 & 0.0345 \\
\hline Black & -0.0654 & 0.0350 & age & 0.0215 & 0.0008 \\
\hline White & 0.2188 & 0.0174 & Age60 & -0.1998 & 0.0274 \\
\hline Yellow & 0.4010 & 0.0769 & f_kind2 & 0.0790 & 0.0199 \\
\hline dcwest & -0.0710 & 0.0377 & Constant & -3.5883 & 0.0494 \\
\hline
\end{tabular}

Table 6

Determinants of $\ln P_{i}^{S}$

$\mathrm{N}=8267$, Log-Likelihood $=-2640.38$

\begin{tabular}{|l|c|c|l|c|c|}
\hline Variable & Estimate & Standard Error & Variable & Estimate & Standard Error \\
\hline \hline Constant & -0.020817 & 0.127874 & Mixed & -0.211478 & 0.047998 \\
\hline Male & -0.227694 & 0.047326 & Asian & 0.273869 & 0.293929 \\
\hline Migrator & 0.150101 & 0.199747 & Age & 0.019145 & $2.03127 \times 10^{-3}$ \\
\hline ED (5-8 yrs) & 0.387136 & 0.054480 & Age > 60 & -0.105695 & 0.074067 \\
\hline ED (9-12 yrs) & 0.845308 & 0.058539 & Income & $1.99052 \times 10^{-4}$ & $9.27403 \times 10^{-6}$ \\
\hline ED (12+ yrs) & 1.34218 & 0.074263 & Employee & -0.235912 & 0.053343 \\
\hline North & -0.100590 & 0.094918 & Self-Employed & -0.255233 & 0.053334 \\
\hline Northeast & -0.135340 & 0.067079 & Domestic Worker & -0.539780 & 0.119628 \\
\hline Center-West & 0.140623 & 0.069616 & Metro 1 & -0.025042 & 0.051464 \\
\hline Southeast & 0.110980 & 0.054015 & Metro 2 & -0.416106 & 0.048105 \\
\hline Black & -0.406526 & 0.092505 & Family Size & -0.043249 & 0.015133 \\
\hline
\end{tabular}

Table 6

Socio-Demographic Effects on Proportional Measure of

Compensating Income Variation From a 50\% Increase in $P_{i}^{S}$

$\mathrm{N}=8267, \mathrm{R}$-squared $=0.659412$

\begin{tabular}{|l|c|c|l|c|c|}
\hline Variable & Estimate & Standard Error & Variable & Estimate & Standard Error \\
\hline \hline Constant & 0.419864 & $4.26638 \times 10^{-3}$ & Mixed & 0.011576 & $1.55395 \times 10^{-3}$ \\
\hline Male & 0.014097 & $1.70310 \times 10^{-3}$ & Asian & -0.076258 & 0.013461 \\
\hline Migrator & $-6.19360 \times 10^{-3}$ & $6.80662 \times 10^{-3}$ & Age & $-9.90146 \times 10^{-4}$ & $6.74201 \times 10^{-5}$ \\
\hline
\end{tabular}




\begin{tabular}{|l|c|c|l|c|c|}
\hline ED (5-8 yrs) & $-6.35279 \times 10^{-3}$ & $1.67772 \times 10^{-3}$ & Age $>60$ & $7.28907 \times 10^{-3}$ & $2.72447 \times 10^{-3}$ \\
\hline ED (9-12 yrs) & -0.037660 & $1.98657 \times 10^{-3}$ & Income & $-2.79919 \times 10^{-5}$ & $7.59087 \times 10^{-7}$ \\
\hline ED (12+ yrs) & -0.249227 & $3.41969 \times 10^{-3}$ & Employee & 0.015117 & $1.95085 \times 10^{-3}$ \\
\hline North & $-1.70524 \times 10^{-3}$ & $3.28471 \times 10^{-3}$ & Self-Employed & 0.014800 & $1.95308 \times 10^{-3}$ \\
\hline Northeast & $-2.96403 \times 10^{-3}$ & $2.16406 \times 10^{-3}$ & Domestic Worker & 0.018112 & $3.42039 \times 10^{-3}$ \\
\hline Center-West & $-8.51688 \times 10^{-3}$ & $2.61514 \times 10^{-3}$ & Metro 1 & $8.84075 \times 10^{-3}$ & $1.89919 \times 10^{-3}$ \\
\hline Southeast & $-6.31576 \times 10^{-3}$ & $2.00423 \times 10^{-3}$ & Metro 2 & 0.015212 & $1.57295 \times 10^{-3}$ \\
\hline Black & 0.017732 & $2.76538 \times 10^{-3}$ & Family Size & $1.51898 \times 10^{-3}$ & $4.27404 \times 10^{-4}$ \\
\hline
\end{tabular}

Table 7

Socio-Demographic Effects on Compensating Income Variation From a 50\% Increase in $P_{i}^{S}$ ( $I_{i}$ Assumed to be Observed) $\mathrm{N}=7644, \mathrm{R}$-squared $=0.402024$

\begin{tabular}{|l|c|c|l|c|c|}
\hline Variable & Estimate & Standard Error & Variable & Estimate & Standard Error \\
\hline \hline Constant & 168.845 & 18.8424 & Mixed & -3.59553 & 6.77750 \\
\hline Male & -33.5610 & 7.68259 & Asian & -22.9243 & 77.1354 \\
\hline Migrator & -50.4782 & 29.9692 & Age & .070672 & .299853 \\
\hline ED (5-8 yrs) & 36.0775 & 7.29269 & Age > 60 & 7.32159 & 12.1295 \\
\hline ED (9-12 yrs) & 66.5361 & 8.97825 & Income & .412354 & 0.00705 \\
\hline ED (12+ yrs) & -81.0515 & 20.8902 & Employee & -51.6785 & 8.84152 \\
\hline North & -1.49066 & 14.5177 & Self-Employed & -47.4406 & 8.76669 \\
\hline Northeast & -58.1799 & 9.58748 & Domestic Worker & -64.0738 & 14.9596 \\
\hline Center-West & -32.8344 & 11.6064 & Metro 1 & -21.8923 & 8.51166 \\
\hline Southeast & -5.66378 & 8.96483 & Metro 2 & -59.2504 & 6.90262 \\
\hline Black & -14.2627 & 12.0434 & Family Size & 20.9211 & 1.87051 \\
\hline
\end{tabular}

Table 8

Socio-Demographic Effects on Proportional Measure of Compensating Income Variation From a 50\% Reduction in $P_{i}^{P}$ $\mathrm{N}=8267, \mathrm{R}$-squared $=0.697525$ 


\begin{tabular}{|l|c|c|l|c|c|}
\hline Variable & Estimate & Standard Error & Variable & Estimate & Standard Error \\
\hline \hline Constant & 0.023276 & $7.38658 \times 10^{-3}$ & Mixed & 0.031053 & $2.69043 \times 10^{-3}$ \\
\hline Male & 0.031212 & $2.94866 \times 10^{-3}$ & Asian & -.144877 & .023305 \\
\hline Migrator & $-7.06999 \times 10^{-3}$ & .011785 & Age & $-2.47009 \times 10^{-3}$ & $1.16727 \times 10^{-4}$ \\
\hline ED (5-8 yrs) & -0.023735 & $2.90472 \times 10^{-3}$ & Age $>60$ & 0.024978 & $4.71700 \times 10^{-3}$ \\
\hline ED (9-12 yrs) & -0.105878 & $3.43945 \times 10^{-3}$ & Income & $-4.35465 \times 10^{-4}$ & $1.31424 \times 10^{-6}$ \\
\hline ED (12+yrs) & -0.465490 & $5.92066 \times 10^{-3}$ & Employee & 0.039820 & $3.37760 \times 10^{-3}$ \\
\hline North & $-4.99453 \times 10^{-3}$ & $5.68696 \times 10^{-3}$ & Self-Employed & 0.038266 & $3.38146 \times 10^{-3}$ \\
\hline Northeast & $-4.25265 \times 10^{-3}$ & $3.74674 \times 10^{-3}$ & Domestic Worker & 0.053847 & $5.92188 \times 10^{-3}$ \\
\hline Center-West & -0.025216 & $4.52770 \times 10^{-3}$ & Metro 1 & 0.017479 & $3.28815 \times 10^{-3}$ \\
\hline Southeast & -0.017338 & $3.47001 \times 10^{-3}$ & Metro 2 & 0.039686 & $2.72332 \times 10^{-3}$ \\
\hline Black & 0.049946 & $4.78783 \times 10^{-3}$ & Family Size & $3.88479 \times 10^{-3}$ & $7.39983 \times 10^{-4}$ \\
\hline
\end{tabular}

REFERENCES

Alvarez, Isabel, " $21^{\text {st }}$ Century, Challenges Facing the Brazilian Health Sector", A Report on the 1998 Roundtable Held in Sao Paulo, Brazil, http:||www.iamericas.org\publications\

Alves, Denisard, "Parametric and Semi-Parametric Modeling of Healthcare Expenditure: A Household Data Analysis for the City of São Paulo", Texto para Discussão no. 5/00, IPEUSP, São Paulo,SP.

Cutler, David M. and Ellen Meara, 1998. " The Medical Costs of the Young and Old: A Forty-Year Perspective" in David A. Wise, editor. Frontiers in the Economics of Aging. Chicago. University of Chicago Press.

De Farias, Pedro Cesar Lima, (1998), "Social Security in Brazil: Problems and Trends", George Washington University, Institute of Brazilian Issues, The Minerva Program, Fall 1998.

Greene, Willian H., 2000. Econometric Analysis, Prentice Hall

Harmeling, Susan, (1999) "Health Reform in Brazil”, Case Study for Module 3:

"Reproductive Health and Health Sector Reform", World Bank Institute.

Long, James Scott, 1997. Regression Models for Caregorical and Limited Dependent Variables, Sage Publications, London

National School of Public Health, Oswaldo Cruz Foundation, Minitsry of Health, Brazil, 
"Health Care Around the World - Brazil".

Parker, S. W., and R. Wong. 1997. "Households Income and Health Care Expenditures in Mexico". Health Policy 40:237-255.

Wong, Rebeca, 2000. "Health, Utilization of Health Care, and Aging in Mexico", Department of Demography. Georgetown University.(unpublished)

World Bank, 1994. Averting the Old Age Crisis: Policies to Protect the Old and Promote Growth. Oxford: Oxford University Press

World Bank (1998), “The Brazilian Health System”, Imapct Evaluation Report, Operations Evaluation Department.

World Bank, 2000. Entering the $21^{\text {st }}$ Century: World Bank Development Report 1999/2000. Oxford: Oxford University Press. 